\title{
International Forum Shopping and Transnational Lawsuits
}

\author{
Harald Koch* \\ Universität Rostock, Juristische Fakultät, Rostock, Germany. \\ E-mail: harald.koch@uni-rostock.de
}

International forum shopping in disputes on liability can be a legitimate procedural strategy for plaintiffs in looking for a favourable jurisdiction. But it demands careful consideration of the pros and cons. In particular, the assumption that the selected court will prefer its own law in any case is not always honoured. The true (and more reliable) motives for forum shopping are aiming at the procedural climate in the selected forum state that seems favourable to the plaintiff (in the case of U.S. courts: jury trial, pre-trial discovery, and class actions). The defendant has but a limited number of remedies and procedural tactics to react upon the claimant's forum shopping or anticipate it - which requires imagination and skilful reflection of all the conceivable steps to be taken by the plaintiff: ADR, anti-suit injunctions (only rarely available in continental Europe, however), declaratory actions for denial, torpedo suits, and, sometimes, the forum-non-conveniens objection. In order to keep undue excesses in forum shopping under control, it seems necessary that the international community, too, in conventions and treaties, agrees on reducing the choices and on banning exorbitant jurisdictions in national laws.

The Geneva Papers (2006) 31, 293-303. doi:10.1057/palgrave.gpp.2510083

Keywords: forum shopping; liability regimes

\section{Forum shopping in general}

\section{The pleasures of "shopping"}

When my wife told me the other day she wanted to go shopping I was not really enthusiastic, it is true. But neither did I consider this business to be really blameable nor is shopping a matter of absolute necessity. What it means, though, in the ordinary comprehension, is a pleasant job both for the shop and the shopper: The shopper enjoys having the choice between different conveniences. And the shop tempts with a variety of offers, and benefits from any deal.

\section{Procedural concepts for "better reactions to developments in liability and insurance"}

How does "forum shopping" fit into this picture? What does it mean and does it make sense in transnational litigation?

\footnotetext{
${ }^{*}$ Professor of Law at the University of Rostock/Germany.
} 
Procedure is a tedious and, for most of the claims specialists, a somewhat annoying subject, since it means exposure to a number of rigid and highly formalized and not very exciting questions of court access, such as:

- commissioning (and paying) a lawyer;

- finding out about the competent court;

- exactly calculating limitation periods;

- caring for service of process;

- defending effectively against unsubstantiated claims, etc.

Yet, sometimes it is procedural strategies rather than the substantive legal situation that is absolutely crucial for the result of a claims dispute, and this is where one of the possible answers can be offered to the question of how to better react on developments in liability and insurance. And that is: by adequately handling transnational litigation and forum shopping in particular. Black's Law Dictionary describes forum shopping by explaining: "Such occurs when a party attempts to have his action tried in a particular court or jurisdiction where he feels he will receive a most favourable judgment or verdict". ${ }^{1}$

\section{Prerequisites for forum shopping}

Shopping around for a friendly forum for someone who claims money from his opponent simply means: looking for a competent court having jurisdiction over the defendant. It presupposes two things: (i) the claim has turned out to be definitely controversial - that is, it cannot be settled out of court; and (ii) there must be choices to be made between different fora.

Hence, forum shopping presents a mere threatening scenario as long as the parties are still negotiating and is impossible when there is only one competent court in cases of exclusive jurisdiction rules.

\section{Legality and limits of forum shopping}

Having described these prerequisites, I think I do not have to spend much effort on disapproving the marked negative and degrading undertone the notion of forum shopping often has in the debate: it is connotated with dirty tricks, unfair (sometimes: illegal) litigation practices; it is supposedly a "nasty concept" and shows that jurisdiction rules are utilized to the benefit of one party only - which is an "altogether unwelcome development" (as an Italian critic puts it $^{3}$ ).

But is it not the very function of a good lawyer to enhance his client's chances of success by finding out about more than one forum amenable and then choosing the

${ }^{1}$ Garner (1999, p. 590).

${ }^{2}$ Geimer et al. (2004, p. 1095) ("böser Terminus”); Lord Justice Simon of Glaisdale (1974, p. 471) ("a dirty word"); Kropholler (1985, p. 165).

${ }^{3}$ Vitta (1982, pp. 1, 6). 
one in which he thinks his case can be most favourably presented ${ }^{4}$ Attorneys have to further their clients' interests so that their failure to exploit the benefits of multiple jurisdictions may even amount to malpractice. ${ }^{5}$

\section{Plaintiff's forum shopping}

\section{Motives for international forum shopping}

How could plaintiff's counsel take advantage of forum shopping? In other words: what are the reasons for choosing a forum in country A rather than in B? I shall try to demonstrate the tactical considerations of forum shoppers by referring to the notorious attractiveness of U.S. courts for plaintiffs: The famous English judge Lord Denning put it this way: "As a moth is drawn to the light, so is a litigant drawn to the United States" 6 and his American colleague Justice Marshall further describes America's magnetism to foreign products liability claimants as follows:

First, all but six of the 50 American states offer strict liability ... Second, the tort plaintiff may choose, at least potentially, from among 50 jurisdictions if he decides to file suit in the United States. Third, jury trials are almost always available in the United States ... Fourth, unlike most foreign jurisdictions, American courts allow contingent attorney's fees and do not tax losing parties with their opponents' attorney's fees... Fifth, discovery is more extensive in American than in foreign courts. ${ }^{7}$

(i) Here we have a number of motives, of reasons for why the plaintiff's counsel tries to litigate the case elsewhere than at home (which usually would be much more convenient, of course). In the well-known Kaprun case, in November five years ago, 152 skiers from different countries were killed by a fire in a cable train tunnel, the fire coming from an overheated radiator. Shortly after the disaster, the notorious American attorney Ed Fagan got the victims' survivors to sue a number of Austrian, German, and American enterprises in a federal district court in New York. ${ }^{8}$

I shall list the motives for plaintiffs to sue in New York once more in order to demonstrate what makes the practitioner in an international case choose a certain court:

- generosity of the forum's liability rules;

- the expected size of damage awards;

- the possibilities of counsel to influence these factors by procedural strategies (such as skillful staging of the presentation of the evidence before a jury or use of effective discovery methods in order to prepare a good case).

This is what you can hear and read time and again in every guide or manual of international civil litigation. What I would like to do now is to re-examine more

\footnotetext{
${ }^{4}$ Lord Justice Simon of Glaisdale (1974).

5 Juenger (1999, p. 317).

${ }^{6}$ Smith Kline \& French Lab., Ltd. vs. Bloch (1983).

${ }^{7}$ Piper Aircraft Co. vs. Reyno (1981, at 255 no. 18).

${ }^{8}$ Cf. Prisching (2004, p. 43).
} 
carefully whether the plaintiff's account on these premises really has no remainder! In other words: are these expectations really answered; these presumptions really straineable?

(ii) Let me start with the first and most important assumption of international forum shopping, that is, the obvious and usually undoubted anticipation of the court applying its own substantive law. When the Kaprun plaintiffs brought suit in New York, of course they expected American liability law to be applied. However, this is anything but evident. It is the rules of Private International Law that provide for criteria determining the law to be applied. And since these private international law rules can be very different in the different countries, the two crucial questions for a forum shopper are: (1) Which court has jurisdiction? (2) Does this court really apply the most favourable law?

(iii) Let me demonstrate this again with reference to the standard goals of forum aspiration, the English and U.S. Courts:

Traditionally, Anglo-American Courts are very generous in accepting their jurisdiction - which is due to an interesting and functional understanding of their judicial system: It does not only serve an abstract idea of justice, but is also regarded as a service that is offered and offensively advertised in the international market. Again, Lord Denning: "You may call this 'forum shopping' if you please, but if the forum is England, it is a good place to shop in: both for the quality of the goods and the speed of service". 9 The same appraisal is true for the U.S., and most of the American states extend their jurisdiction to non-American defendants. Take the New York Long-ArmStatute as an example: it subjects the foreign defendant to New York jurisdiction if he has "minimum contacts" to New York, for example:

- if he does (continuous and substantial) business in New York (which is not a serious barrier in most cases);

- if he commits a tortious act there (production or marketing is necessary);

- if foreign activities result in damages in New York (place of injury);

- or if he has real property there. ${ }^{10}$

This looks as if jurisdiction of a U.S. court can be easily obtained, but there is an old doctrine that enables U.S. courts to deny their jurisdiction even though they found minimum contacts, and that is if they consider themselves as a non-convenient forum (forum non conveniens) - which is a matter of wide discretion. ${ }^{11}$ This procedural instrument is used to keep off cases too artificially connected to a U.S. forum (and you can imagine that forum non conveniens is granted more often in cases with U.S. defendants than in those with U.S. plaintiffs and foreign defendants). ${ }^{12}$

These are the rules of jurisdiction, and they make a certain determination of a competent court nearly unpredictable. Yet, there are always attorneys pleading for suit in the U.S., in particular those who charge their clients fees on an hourly basis: to

\footnotetext{
${ }^{9}$ The Atlantic Star (1972, pp. 705, 709).

${ }^{10} \S 302$, New York Civil Practice Law and Rules, cf. Schack (2003, p. 24).

${ }^{11}$ Cf. Juenger, supra note 5, at 320; Fausten (2005, pp. 1502-1505).

12 Schack (2005).
} 
make inquiries about international jurisdiction, minimum contacts, forum non conveniens is extremely time consuming and, hence, it pays - regardless of success. Even if the prospects of accepting jurisdiction are gloomy, an action may have a certain bargaining value when a settlement out of court is negotiated.

(iv) The question of which law is to be applied in a transnational dispute - more precisely: is it U.S. tort law? - is often part of this threatening scenario plaintiff's attorneys' efforts to display in order to make the opponent settle the case in favour of their client. There is talk of American product liability rules extremely favourable to victims, of high damage awards, of U.S. style punitive damages, of easy evidence, and the like. ${ }^{13}$

This is a conflict-of-laws problem and a factor in the deliberations of the parties that is often neglected because lawyers rashly tend to identify two problems that are not the same: the competent court and the application of its own law. Jurisdiction and law to be applied have to be carefully distinguished, however, since they follow quite different rules nearly everywhere. Even if, in a given tort case, an American court has admitted jurisdiction, its conflict rules do not as a matter of course result in the applicability of U.S. liability law on the merits: It does not go without saying in cases where the accident occurred outside the U.S., injuries/damages did not appear in the U.S., or no other points of contact to the U.S. exist. Rather, it is generally the place-of-the-injury rule that prevails in most of the U.S. ${ }^{14}$ And so, even a U.S. Court may apply foreign tort law if the place of the injury is outside the U.S. - unless there is a more significant relationship to the foreign state that disproves the presumption for the place of injury's law (such as domicile of the parties).

So again, a forum shopper has to be very careful in ascertaining the result of his calculus: he must present convincing evidence for the court's jurisdiction and for the law to be applied, that is,

- minimum contacts to the forum state for its jurisdiction;

- occurrence of injuries there or another more significant relationship.

There is one question, however, where the plaintiff's presumption that the foreign court will apply its own law may be justified. It pertains to the size of damages awarded by the court. American courts - in the past at least - regarded the damage issue as a matter of procedure, not of substantive law. ${ }^{15}$ Since courts everywhere in procedural questions go by their own law (lex fori), they used to judge the substance and the amount of damages according to their own law as well.

\section{More realistic attractions: procedure}

Given these rather complicated considerations I am insinuating to the forum shopper you might question whether this is a realistic scenario. It is very unlikely that a plaintiff's attorney frequently in advance probes into difficult questions of jurisdiction

\footnotetext{
${ }^{13}$ Cf. Fausten (2005).

${ }^{14} \S 146$ Restatement of Conflicts 2nd.

15 Koch (2002).
} 
and private international law. What makes him choose a foreign court, then (preferably a U.S. court)? It seems it is not so much the substantive law he hopes the court will apply, but rather the procedural advantages a foreign forum might offer ${ }^{16}$ and here I'm coming back to Justice Marshall's points mentioned earlier:

(i) The law of evidence may be an interesting factor motivating the forum shopper. Take the different rules of expert evidence on the continent and in common law countries where the parties can present (and prepare) their own experts.

(ii) The means of pre-trial discovery are used in product liability cases to find out about crucial defects and negligences in manufacturing the product.

(iii) Sometimes, speed and efficiency of a country's procedure make up for the choice of forum too. We have a number of recent examples in European countries already where the period of time between service of process and trial was considered as intolerable under human rights standards, so that forum shopping to prevent undue delay makes sense.

(iv) Also, sometimes it is the differences in the costs of proceedings, in particular the American as opposed to the European principles of charging the costs to the party causing them rather than to the loser, that might induce plaintiffs to chose another forum.

(v) Trial by jury for American attorneys seems to be an important possibility to influence the result of a case, both with respect to a defendant's liability and the size of a possible award. Thus, an American forum can be particularly attractive, and this presents a motive for forum shopping as well.

(vi) One more American speciality attracts particularly those plaintiffs who see themselves in the same position as a larger number of fellows similarly situated by the defendant's conduct: This is the situation where a class action - if certified - promises multiplied awards, hence more publicity and a better bargaining position and - last but not least - a bigger piece of the cake for the plaintiff's attorney.

(vii) Finally, the chances of execution of an expected judgement always was an argument for choosing a suitable forum: if the judgement cannot be enforced in the forum state because the defendant has no assets, there it might be a better idea to sue him where execution is more realistic. "Forum shopping" and "asset hunting" can hereby be combined, which is a common issue in maritime law, where we often have a one-ship company whose holder is hard to identify, and then it is crucial to secure jurisdiction by stopping the ship in the forum's port.

On the whole, I think the procedural environment or, to put it less formally, the legal climate of a foreign jurisdiction plays a crucial role for the plaintiff who tries to get his case before a friendly judge. The efforts to get the court to apply a certain substantive law on the other side are less important, because the assumption connected to them is not really reliable: you can never exactly tell whether the court will really apply the law you hope for. Even if it does, who can guarantee that a Californian judge handles German liability provisions the same way as a German court?

\footnotetext{
${ }^{16}$ Siehr (1984, pp. 124-128 et seq).
} 


\section{Forum shopping from the defendant's perspective}

\section{General objections against forum shopping}

Looking for a court that has jurisdiction over the defendant and choosing among several fora for the most favourable is the plaintiff's privilege: the defendant has no choice. To make up for this unequal treatment of parties, the basic rule of jurisdiction in most countries and international treaties is actor sequitur forum rei, that is, the plaintiff has to go to the defendant's court and ask for relief there. But if there are statutory alternatives (such as a court at the place of the injury, or where assets are to be found), then the defendant again is in poor condition. This of course is somewhat delicate because of its unequal treatment of the parties.

There are two ways for the international community to redress the balance: ${ }^{17}$ one is reducing the number of available fora to be chosen by the plaintiff. The European community tries to do that with its Jurisdiction Regulation (Brussels I-Regulation) not very successfully, indeed - in enumerating exclusively the exceptions to the principle of the defendant's forum (art. 5,6). In particular, the so-called exorbitant fora (like the plaintiff's forum for French citizens, or the place of assets under German law) cannot be practised within Europe! This tendency to reduce forum alternatives to be chosen in international treaties should be increased because of the obvious disadvantages to judicial economy too. ${ }^{18}$

The second possibility of reducing the alternatives and hence redressing the balance is to remove the true attractions for forum shopping, and that is the speculations on the applicable law. If the private international law rules in all countries were the same, then it would not make sense to look around for a court applying the best law available - no matter where you sue the defendant, every court would apply the same law (and hence, ideally come to the same result). Within Europe the efforts to harmonize, for example, the different international tort law rules have been quite successful: the so-called Rome-II-Regulation is about to be promulgated, which considerably reduces the forum shopping potential.

\section{More realistic attractions: procedure}

These are measures to be taken by the state community to control forum shopping. More interesting for our discussion on possible reactions to developments in liability and insurance is the quest for defence strategies vis-à-vis forum shopping.

(i) Needless to say that before entering into litigation it is necessary to exhaust outof-court negotiation and conciliation possibilities. All kinds of ADR measures, including mediation, are superior to being sued in court because they can avoid the notorious disadvantages of forum shopping in favour of the claimant. In some, though not in all, cases, agreeing in advance on means of dispute resolution, even on a forum acceptable to both parties, might be a way to anticipate controversies not to be solved otherwise.

\footnotetext{
${ }^{17}$ Cf. Kropholler (1985, p. 165).

${ }^{18}$ Von Bar and Mankowski (2003, § 5 nos. 157 et seq).
} 
(ii) If out-of-court dispute resolution fails, the defendant might try to stop the claimant from suing him abroad by taking the defence initiative himself and bringing an antisuit injunction. It seeks to prohibit the plaintiff from prosecuting his claim in a court of his choice as the potential defendant applies for an injunction in his country. This is a procedural instrument that cannot be used in every country, however. But in England and the U.S., they are weapons in the defendant's arsenal absolutely in use. They are admitted and issued if the claimant's suit in another country is regarded as "vexatious or oppressive", ${ }^{19}$ as we saw in the notorious antitrust dispute between the first trans-atlantic cheap carrier Freddy Laker and the established airlines in the 1980s, where English and U.S. Courts fought against each other with a series of antisuit injunctions. $^{20}$

In continental Europe, a general "right not to be sued abroad" is not recognized. Even if a plaintiff took advantage of his forum shopping options and brought suit in the U.S. against a European defendant, for example a manufacturer of a purportedly defective product, an injunction to stop him from further prosecuting his claim would not lie here, since forum shopping and suing in a foreign court consenting to its jurisdiction is not per se illegal. This would be necessary for instance under German law to bring a tort action for an injunction. Only in extreme cases, when bringing suit abroad amounts to intentional and unconscionable harm to the defendant (cf. $\$ 826$ BGB), that is, in obvious abuse-of-right situations, there might be a chance for the defendant (even on the continent) to lodge an antisuit injunction. ${ }^{21}$ We really do not have practical experiences with those measures, however, so that it is hard to predict in what situation the courts will really follow this unconscionability argument. In any case, I should add that under the European Jurisdiction (Brussels-I-Regulation) antisuit injunctions are impossible: The ECJ last year ruled out this possibility, as the courts of every member state deserve the minimum of confidence in their ability to decide unbiased on their own jurisdiction. ${ }^{22}$

(iii) For the potential defendant to a liability action, it might be more promising to argue on the merits - "I am not liable" - rather than procedurally: This is possible in an action for declaratory relief where the plaintiff (the potential debtor) seeks a declaration that he is not liable (in Germany: negative declaration). Such an action denying liability can be brought preventively, that is, already before the opponent takes the initiative to sue, and hence at least the Continent creates a bar to a later action by the claimant. Against the second action the objection of pending suit (lis pendens) can be raised (art. 27 Brussels-I-Regulation).

The chance (and the problem) with this declaratory action for denial, again, is the jurisdiction of the court where this relief is sought: when we are talking about the defendant's reactions to forum shopping here, we have a real possibility for the (potential) defendant to prevent the claimant from shopping around. Take the example of a European manufacturer $\mathrm{M}$ being held liable by an American claimant $\mathrm{C}$.

\footnotetext{
${ }^{19}$ Schack (2002, no. 770).

${ }^{20}$ Laker Airways vs. Sabena (1984); Lange (1986, p. 655).

${ }^{21}$ Baum (1994, pp. 184, 194 et seq).

22 Turner vs. Grovit (2004, p. 425); Kropholler (2005, Art. 27 no. 20).
} 
If $\mathrm{M}$ wants to anticipate an American lawsuit against him (and preempt $\mathrm{C}$ ), then he can bring a declaratory action against $\mathrm{C}$ at home (in Europe). There is a good argument for a European court's jurisdiction as it is the place of the wrong, the forum delicti, where the product was manufactured..$^{23}$ Usually European courts would accept their jurisdiction under this theory (although there are some doubts as to its convincing power ${ }^{24}$ ).

There is one exception I should mention, and that is the so-called torpedo suit. This was an idea of clever attorneys taking advantage of some countries' notorious problems with court delay. They helped their clients unwilling to pay their debts by bringing an action denying their liability preferably in a notoriously slow justice country in order to block the creditor wanting to litigate in a faster judicial system (via lis pendens objections). But if this is done solely for delaying purposes, then the unwilling debtor runs the risk of being held liable for obstruction of justice. ${ }^{25}$

(iv) In common law countries, there is one more commonsensical answer to plaintiffs who overdo their forum shopping and try to force unsuspecting defendants into a forum extremely unsuitable, and this is the objection already mentioned: forum non conveniens. It means that upon a defendant's motion courts may decline to exercise their jurisdiction on the ground that the location the plaintiff selected for the case is grossly inconvenient and that there is another alternative forum available that is obviously more closely connected to the controversy. ${ }^{26}$ This will be assumed, for instance, if access to needed proof (witnesses, premises to be inspected) is significantly easier in another forum, or if a real interest of the court originally addressed cannot be recognized. What is unusual for continental Europeans is the wide discretion the original court has in deciding whether it wants to hear the case or to dismiss the action as grossly inconvenient. But it is a very useful and sometimes necessary measure to control the generosity of common law jurisdictions and to dismiss forum shoppers who obviously use their choices in an imposing and abusive way.

(v) One last defence strategy: In a damage suit between the injured party and the person liable, it may make sense for the insurer to participate, and here we have forum shopping options too: there are a number of procedural instruments available in most countries for the insurer to participate, for example, intervention, tender of defence (vouching-in), third party practice, or even informal control of the defence by the insurer. ${ }^{27}$ Concerning jurisdiction requirements, there is a very important difference between these forms of third party practice: tender of defence, the French assignation en garantie, or the German Streitverkündung are brought in the same court as the main case. This is also the general rule in the European Jurisdiction Regulation (Art. 6 No. 2). ${ }^{28}$ The court exercises only some kind of "lenient" jurisdiction over the insurer who is not really a full party but only someone who might be answerable to an indemnity claim later, and thus is only notified of dependency of the action. This is completely

\footnotetext{
23 Schack (2002, no. 295); Kropholler (2005, Art. 5, no. 78).

${ }^{24}$ Baum (1994, pp. 185, 200) supra note 21.

${ }^{25}$ Schack (2002, Rn. 762 a).

${ }^{26}$ Juenger (1999, pp. 317, 322 et seq).

${ }^{27}$ For these examples of third party practice, see Lüke (1993); Koch (1986, p. 11); Mansel (1994, p. 63).

${ }^{28}$ Cf. European Court of Justice (2005).
} 
302

different in the case of a true third party complaint (impleader), which makes the indemnitor a real party, a further defendant in the litigation with all the procedural consequences as to the necessary jurisdiction, service of process, or the role of the parties (as opposed to a merely notified supporter), the costs of the lawsuit, or the visibility for a jury (deep pocket syndrome).

These alternatives leave some room for different strategies for the defendant - not for forum shopping in the direct sense, it is true, but for options that are contingent on jurisdiction in a convenient or inconvenient forum, where the original liability action is pending. And these options can be influenced by the insurance! The fact that open intervention and third party complaints in international insurance litigation are rarely used - as opposed to tender of defence or vouching in - shows that the advantages of a mere background role of the insurer in a liability case are outweighing the prima-facie, maybe more attractive, option for a third party defendant.

\section{Conclusion}

To sum up, five points can be made in conclusion:

1. International forum shopping in disputes on liability is very popular with the plaintiff's bar. It is legitimate but demands careful consideration of the pros and cons.

2. In particular, the assumption that the selected court will prefer its own law in any case is not always honoured.

3. The true (and more reliable) motives for forum shopping are aiming at the procedural climate in the selected forum state that seems favourable to the plaintiff.

4. The defendant has but a limited number of remedies and procedural tactics to react upon the claimant's forum shopping or to anticipate it - which requires imagination and skillful reflection of all the conceivable steps to be taken by the claimant.

5. In order to keep undue excesses in forum shopping under control, it seems necessary that the international community, too, in conventions and treaties, agrees on reducing the choices and on banning exorbitant jurisdictions in national laws.

\section{References}

Baum (1994) 'Abwehrklagen gegen U.S.-amerikanische Produkthaftungsklagen?', in A. Heldrich and T. Kono (eds) Herausforderungen des internationalen Zivilverfahrensrechts, Tübingen: Mohr Siebeck.

European Court of Justice (2005) ECJ 26. 5. 05, case no. 77/04 - GIE Réunion Europénne et al. v. Zurich Espana, Soptrans (Anm. Heiss), Versicherungrecht 31: 1001-1002.

Fausten, T. (2005) 'Die Einbeziehung ausländischer Geschädigter in Zivilverfahren in den USA - rechtliche Aspekte des "Forum Shopping",, Versicherungrecht 31: 1502-1505.

Garner, B. (ed) (1999) Black's Law Dictionary, 7th edn., Stamford, CT, and London: West Group Publisher.

Geimer, R., Geimer, E. and Geimer, G. (2004) Internationales Zivilprozessrecht, 4th edn., Köln: Otto Schmidt.

Juenger (1999) 'Forum non Conveniens - Who needs it?', in R. Geimer (ed) Wege zur Globalisierung des Rechts, München: CH Beck, p. 317.

Koch, H. (1986) 'Streitverkündung und Drittklage im amerikanisch-deutschen Prozeß', Zeitschrift für Vergleichende Rechtswissenschaft 85: 11. 
Koch, H. (2002) 'Forum shopping', in H. Koch and A. Willingmann (eds) Modernes Schadensmanagement bei Großschäden, Baden-Baden: Nomos Verlagsgesellschaft, pp. 15-20.

Kropholler, J. (1985) 'Das Unbehagen am Forum Shopping', in Henrich and Von Hoffmann (eds) Festschrift für Karl Firsching, München: C.H. Beck, pp. 165-173.

Kropholler, J. (2005) Europäisches Zivilprozessrecht, 9th edn., Frankfurt: Recht und Wirtschaft.

Laker Airways vs. Sabena (1984) 713 F. 2d 909 (D.C. Cir. 1984).

Lange, D.G. (1986) 'Der Justizkonflikt zwischen den USA und Europa - dargestellt am Beispiel des Falles Laker', in W.J. Habscheid (ed) Der Justizkonflikt mit den Vereinigten Staaten, Bielefeld: Gieseking, Ernst und Werner, GmbH, Verlag, pp. 65-92.

Lord Justice Simon of Glaisdale (1974) in The Atlantic Star, A.C. 436, 471.

Lüke, W. (1993) Die Beteiligung Dritter im Zivilprozess, Tübingen: Mohr Siebeck.

Mansel, J. (1994) 'Streitverkündung (vouching in) und Drittklage (3rd party complaint) im Zivilprozeß', in A. Heldrich and T. Kono (eds) Herausforderungen des internationalen Zivilverfahrensrechts, Tübingen: Mohr Siebeck.

Piper Aircraft Co. vs. Reyno (1981) 454 US 235.

Prisching, M. (2004) 'Strategien amerikanischer Anwälte bei Katastrophenfällen mit internationalem Bezug: Versuche einer Schadenersatzmaximierung am Beispel Kaprun', Zeitschrift für Rechtsvergleichung 45(2): 43-55.

Schack, H. (2002) Internationales Zivilverfahrensrecht, 3rd edn., München: Beck Juristischer Verlag.

Schack, H. (2003) Einführung in das US-amerikanische Zivilprozessrecht, 3rd edn., München: C.H. Beck.

Schack, H. (2005) 'Unglücke in Europa - Klagen in den USA', in B. Bachmann, S. Breidenbach, D. CoesterWaltjen, B. Hess, A. Nelle and C. Wolf (eds) Beiträge zum Internationalen Verfahrensrecht und zur Schiedsgerichtsbarkeit, Tübingen: Mohr Siebeck, pp. 839-847.

Siehr, K. (1984) 'Forum shopping im internationalen Rechtsverkehr', Zeitschrift für Rechtsvergleichung 25 : $124-128$.

Smith Kline \& French Lab., Ltd vs. Bloch (1983) 2 All E.R. 72.

The Atlantic Star (1972) 3 All E.R. 705, 709 (C.A.).

Turner vs. Grovit (2004) Case no. 159/02, IPRax 2004.

Vitta, E. (1982) 'The impact in Europe of the American "conflicts revolution"”, American Journal of Comparative Law 30: 1-18.

von Bar, C. and Mankowski, P. (2003) Internationales Privatrecht, Vol I, 2nd edn., München: Beck Juristischer Verlag.

\section{About the Author}

Harald Koch, J.D. (Staatsexamen) in Hamburg (1967, 1971), Dr. iur. and Dr. iur. habil in Hamburg (1972, 1983), Professor of Law in Hamburg (1979-1981), Hannover (1981-1992), Rostock (since 1992); Director of the Institute of International Law and Judge at the Rostock Court of Appeal; Guest Professor at the University of California in Berkeley and Tulane University, New Orleans, LA. 